\title{
SINTESIS BIODIESEL DARI MINYAK BIJI NYAMPLUNG (Callophyllum innophylum L.) DENGAN METODE ULTRASONOKIMIA
}

\author{
Muh. Taufiq M. Bintang*, Aisyah, \& Asri Saleh \\ Jurusan Kimia, Fakultas Sains dan Teknologi, UIN Alauddin Makassar \\ *Alamat Korespondensi: taufiq89bintang@gmail.com
}

\begin{abstract}
Abstrak: Indonesia merupakan negara berkembang yang membutuhkan suplai energy namun ketersediaannya semakin menipis. Oleh karena itu, energi alternatif diperlukan untuk memenuhi kebutuhan energi. Salah satu sumber energi alternative yang sedang dikembangkan adalah biodiesel. Tujuan dari penelitian ini adalah untuk optimalisasi konversi pembentukan biodiesel dan menentukan komponen biodiesel yang terbentuk. Biodisel pada penelitian ini diproduksi dari minyak biji nyamplung (Callophyllum innophyllum L.) dengan mereaksikan dengan methanol dengan rasio 1:6 menggunakan $\mathrm{KOH} \mathrm{0,5 \%} \mathrm{sebagai} \mathrm{katalis} \mathrm{dan} \mathrm{direaksikan} \mathrm{menggunakan}$ metode ultrasonik kimia dengan variasi waktu 45, 60 atau 75 menit. Biodiesel yang dihasilkan kemudian dianalisis dengan menggunakan FTIR sehingga dapat menunjukkan spectrum ester asam lemak panjang. Biodiesel juga dianalisis dengan GC-MS dan hasilnya menunjukkan bahwa komponen utamanya adalah metil oleat, metil palmitat, metil sterarat dan metil linoleat.
\end{abstract}

Kata kunci: nyamplung, ultrasonik kimia, biodisel, FAME, esterifikasi

Abstract: Indonesia as developing country needs massive suply of energy but in the other hands the availability of energy is getting reduce. So that alternative energy is needs to fullfil the energy demand. One of the alternative that recently investgated is biodiesel. The aim of this research is to establish biodiesel optimal conversion value and to determine the component of biodiesel. Biodiesel is produced from nyamplung seed oil

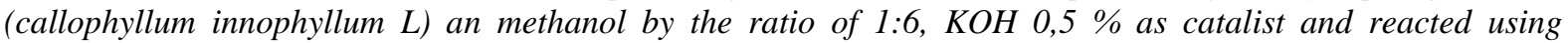
chemical ultrasonic method in various reaction time 45, 60, 75 minutes. Biodiesel were analyzed with FTIR that show spectrum as long carbon fatty acid ester. Biodiesel is also analyzed by GC-MS and discovered that the major component are methyl oleic, methyl palmitate, methyl steric and methyl linoleic.

Keywords: Nyamplung, chemical ultrasonic, biodiesel, FAME, transesterification.

\section{PENDAHULUAN}

Indonesia sebagai negara berkembang memerlukan pasokan energi yang besar untuk keperluan industri dan transportasi dalam negeri, akan tetapi produksi energi dalam negeri utamanya minyak bumi tidak cukup untuk memenuhi kebutuhan dan konsumsi energi nasional, sehingga pemerintah sering mengimpor minyak bumi untuk memenuhi kebutuhan energi nasional. Oleh karena itu diperlukan sumber energi alternatif baru untuk menggantikan penggunaan bahan bakar minyak.Menurut Handbook of Energy and Economy Statistics of Indonesia 2012, konsumsi energi final Indonesia sebesar 793,942 ribu BOE (Barrel of Oil Equivalent) pada tahun 2010 dan menjadi 834,717 ribu BOE pada 2011. Artinya terjadi peningkatan konsumsi final energi sebesar $3,61 \%$ dan kemungkinan akanterus naik setiap tahunnya (PUSDATIN ESDM, 2012). Dalam hal pengembangan energi alternatif, Indonesia sebenarnya memiliki banyak sekali sumber daya alam yang bisa dimanfaatkan seperti hasil perkebunan yang melimpah yang dapat dijadikan biofuel, seperti biodiesel. Biodiesel merupakan suatu bahan bakar alternatif yang terbuat dari bahan nabati dan potensial digunakan sebagai bahan bakar minyak. Pengolahan biodiesel secara konvensional biasanya memerlukan pemanasan, penggunaan katalis basa, dan pengadukan mekanis. Akan tetapi, proses konvensional ini memerlukan waktu yang lama sehingga waktu dan biaya pengolahan menjadi meningkat. Dalam penelitian yang dilakukan Fredric (2013) pembuatan biodiesel dari minyak biji kapuk membutuhkan waktu hingga 90 menit untuk memperoleh nilai konversi biodiesel sebesar 97,22\%. Suirta (2009) yang melakukan penelitian preparasi biodiesel minyak jelantah kelapa sawit dengan waktu reaksi selama 150 menit menghasilkan konversi biodiesel sebesar 78,5\%.

Selain metode konvensional, ada beberapa metode lain yang digunakan untuk menyintesis biodiesel, salah satunya adalah metode ultrasonokimia. Penggunaan instrumen ultrasonik dimaksudkan untuk tujuan efisiensi pengolahan biodiesel. Gelombang ultrasonik tidak memerlukan panas langsung dan pengadukan mekanis sehingga waktu pengolahan biodiesel menjadi lebih cepat. Menurut penelitian yang dilakukan Budiyanto dkk (2012), metode ultrasonokimia mengkonversi minyak nabati menjadi biodiesel lebih cepat dari metode konvensional. Metode ultrasonikimia hanya membutuhkan waktu reaksi 40 menit sedangkan metode konvensional membutuhkan 360 menit. Putri dkk. (2013) menyatakan reaksi transesterifikasi minyak kelapa selama 60 menit menggunakan metode ultrasonik menghasilkan konversi optimal 
sebesar $85,66 \%$ sedangkan metode konvensional hanya menghasilkan konversisebesar 20,15\%. Deng et al. (2010) dalam penelitian transesterifikasi ultrasonik minyak jarak pagar dengan proses dua langkah, menemukan bahwa dengan bantuan ultrasonik maka waktu reaksi dapat dipersingkat dari 4 jam menjadi 90 menit.

\section{BAHAN DAN METODE}

Alat

Alat yang digunakan pada penelitian ini adalah: Gas Chromatography Mass Spectrofotometer (GCMS) agilent GC Type 7890 A; MS type 5975, FTIR Shimadzu IR-Prestige, seperangkat peralatan Ultrasonik Krisbow $47 \mathrm{KHz}$, pengepres mekanik, peralatan soklet, piknometer, viskometer Oswald, corong pisah, rotary evaporator, termometer, hot plate, magnetik stirer dan peralatan-peralatan gelas.

\section{Bahan}

Bahan yang digunakan pada penelitian ini adalah biji nyamplung yang diperloeh dari Desa Barombong Kabupaten Takalar dan Desa Nipa Kabupaten Bone Sulawaesi Selatan, etanol, aquadest, asam asetat, asam fosfat $20 \%$, indikator phenoftalein $(\mathrm{PP})$, asam klorida $(\mathrm{HCl})$, kalium hidroksida $(\mathrm{KOH})$, metanol, $n$-heksana dan asam sulfat $\left(\mathrm{H}_{2} \mathrm{SO}_{4}\right)$, kertas lakmus.

\section{Prosedur kerja \\ Ekstraksi}

Biji nyamplung dirajang hingga menjadi butiran-butiran yang lebih kecil kemudian dikeringkan dibawah sinar matahari selama kurang lebih tujuh hari. Biji nyamplung kemudian dimaserasi memakai pelarut $n$-heksana selama tiga hari dengan penggantian pelarut setiap 24 jam. Larutan campuran minyak dan pelarut kemudian dipisahkan menggunakan alat destilasi.

\section{Degumming}

Proses degumming dilakukan dengan cara sebanyak 300 gram minyak biji nyamplung hasil ekstraksi dipanaskan dengan suhu $70^{\circ} \mathrm{C}$. Kemudian minyak tersebut ditambahkan Asam fosfat 20\% sebanyak $0,2 \%$ dari berat minyak lalu diaduk selama 25 menit setelah itu minyak dimasukkan kedalam corong pisah, didiamkan selama 24 jam, minyak lalu dipisahkan dari getah yang terbentuk. Minyak akan berada dibagian atas sedangkan getah akan berada di bagian bawah.

\section{Standarisasi KOH}

Standarisasi $\mathrm{KOH}$ dilakukan dengan cara larutan $\mathrm{KOH} 0.1 \mathrm{~N}$ dibuat didalam labu ukur $100 \mathrm{~mL}$ dan larutan $\mathrm{HCl} \quad 0.1 \mathrm{~N}$ didalam labu ukur 100 mL.Larutan $\mathrm{HCl} 0.1 \mathrm{~N}$ dimasukkan ke dalam buret asam $50 \mathrm{~mL}$ hingga tanda batas miniskus. Larutan $\mathrm{KOH} 0.1 \mathrm{~N}$ sebanyak $20 \mathrm{~mL}$ dimasukkan ke dalam erlenmeyer dengan menambahkan indikator PP lalu menitrasinya dengan $\mathrm{HCl}$ yang ada dalam buret asam.Volume $\mathrm{HCl}$ yang digunakan dicatat setelah titrasi.

\section{Penentuan angka asam}

Penentuan angka asam dilakukan untuk mengetahui banyaknya $\mathrm{KOH}$ yang digunakan dalam proses netralisasi. Penentuan angka asam dilakukan dengan cara minyak nyamplung dipipet sebanyak 10 mL. Kemudian etanol $95 \%$ sebanyak $25 \mathrm{~mL}$ dipipet lalu ditambahkan kedalam minyak nyamplung lalu direfluks hingga mendidih selanjutnya ditambahkan indikator PP, kemudian dititrasi dengan $\mathrm{KOH} 0,1 \mathrm{~N}$ hingga larutan berwarna merah muda. Volume titrasi kemudian dicatat.

\section{Esterifikasi}

Esterifikasi dilakukan untuk menurunkan angka asam dari minyak biji nyamplung yang sangat tinggi. Esterifikasi dilakukan dengan cara minyak hasil degumming ditimbang sebanyak 276,4276 gram kemudian dicampurkan dengan campuran metanol sebanyak 192 gram dan asam sulfat pekat sebanyak 0,9010 mL. Campuran minyak dan metanol direaksikan menggunakan magnetik stirrer selama 1 jam dengan suhu $64^{\circ} \mathrm{C}$. Selanjutnya dimasukkan kedalam corong pisah dan didiamkan selama 24 jam.

\section{Netralisasi}

Proses netralisasi dilakukan dengan cara minyak nyamplung ditimbang sebanyak 100 gram. Kemudian, KOH sebanyak 0,1421 gram dan $20 \mathrm{~mL}$ etanol $96 \%$ ditambahkan kedalam minyak,kemudian minyak dipanaskan menggunakan magnetic stirrer dengan suhu $\pm 64{ }^{\circ} \mathrm{C}$ selama 10 menit. Kemudian campuran dimasukkan ke dalam corong pisah lalu ditambahkan dengan $n$-heksana sebanyak $100 \mathrm{~mL}$ dan didiamkan selama 24 jam, lalu kedua campuran dipisahkan, dimana yang berada pada bagian atas adalah $n$-heksana yang mengikat senyawa non polar yaitu minyak nyamplung dan pada bagian bawah adalah etanol yang mengikat senyawa polar yaitu $\mathrm{KOH}$.

\section{Transesterifikasi}

Transesterifikasi dilakukan dengan cara menimbang $\mathrm{KOH}$ sebanyak 0,1658 gram kemudian dicampurkan dengan metanol sebanyak 19,2 gram dan diaduk selama 15 menit agar homogen. Selanjutnya minyak nyamplung sebanyak 27,643 gram ditambahkan pada Campuran metanol dan $\mathrm{NaOH}$ kemudian campuran dimasukkan dalam alat ultrasonik dan direaksikan selama 45 menit. Setelah direaksikan dalam alat ultrasonik minyak dimasukkan dalam corong pisah untuk memisahkan biodiesel dan gliserol. biodiesel berada dibagian atas dan gliserol dibagian bawah. biodiesel dicuci dengan air panas hingga $\mathrm{pH}$ netral. biodiesel yang bercampur dengan air kemudian dipisahkan dengan alat sentrifuge. Setelah itu dipanaskan pada suhu $105^{\circ} \mathrm{C}$ untuk 
menghilangkan kandungan airnya. Jika masih ada kandungan air yang terdapat pada biodiesel maka ditambahkan natrium sulfat. Prosedur kerja diulangi dengan variasi waktu 60 menit dan 75 menit.

\section{HASIL DAN PEMBAHASAN}

\section{Esterifikasi}

Minyak hasil degumming memiliki angka asam yang sangat tinggi yaitu $20,5752 \mathrm{mg}-\mathrm{KOH} / \mathrm{g}$. Angka asam yang sangat tinggi membuat minyak tersebut belum bisa digunakan untuk reaksi transesterifikasi sehingga diperlukan perlakuan pendahuluan yaitu metode esterifikasi dengan cara mereaksikan asam lemak bebas minyak dengan metanol dan katalis asam sulfat dengan perbandingan molar 1:6 dan asam sulfat $0,6 \%$ berat minyak. Esterifikasi dilakukan sebanyak dua kali sehingga didapatkan angka asam sebesar 1,4272 mg-KOH/g.

\section{Transesterifikasi}

Keberhasilan reaksi transesterifikasi bergantung pada beberapa faktor, yaitu: suhu, kecepatan pengadukan, rasio mol alkohol dengan minyak dan katalis. Faktor suhu dan kecepatan pengadukan diatasi dengan penggunaan alat ultrasonik, sedangkan perbandingan mol minyak dan alkohol yang rendah mengakibatkan reaksi tidak berjalan sempurna sedangkan jika terlalu tinggi akan menyulitkan pemisahan gliserol dan biodieselnya. Pada penelitian ini minyak nyamplung direaksikan dalam alat ultrasonik dengan variasi waktu 45 menit, 60 menit dan 75 menit. Setelah minyak direaksikan dengan gelombang ultrasonik, campuran dimasukkan kedalam corong pisah dan di diamkan selama 24 jam hingga membentuk dua fase, dimana fase lapisan bawah adalah gliserol dan fase bagian atas adalah metil ester atau biodiesel. Fase bagian atas tersebut kemudian ditambahkan aquadest yang sudah dipanaskan lalu ditambahkan asam asetat hingga mencapai $\mathrm{pH}$ netral. Randemen biodiesel disajikan pada Tabel 1. Rendemen biodiesel paling banyak didapatkan dari reaksi ultrasonik selama 75 menit yaitu sebanyak 42,7399\% dari berat minyak yang direaksikan kemudian sebanyak 27,0900\% dan yang paling sedikit adalah reaksi ultrasonik selama 60 menit yaitu sebesar 25,6201\%. Dari hasil penelitian ini dapat dilihat hasil rendemen yang sedikit acak antara rendemen reaksi 45 menit dan 60 menit dimana reaksi 45 menit rendemennya lebih banyak daripada rendemen 60 menit. Hal ini diakibatkan berkurangnya minyak dan biodiesel yang dihasilkan saat proses pencucian dan proses pemisahan air setelah pencucian.

\section{Analisa gugus metil ester dengan FTIR}

Untuk membuktikan bahwa yang dihasilkan dalam proses transesterifikasi adalah metil ester, maka dilakukan uji menggunakan FTIR (Fourier Transform Infrared) untuk mengetahui gugus-gugus fungsi yang terbentuk. Biodiesel yang dihasilkan dari penelitian ini dianalisa menggunakan alat instrumen FTIR untuk membuktikan dan meyakinkan bahwa hasil penelitian ini memiliki gugus fungsi metil ester yang merupakan gugus fungsi utama dari biodiesel. Hasil analisis FTIR sampel yang direaksikan selama 45 menit disajikan pada Gambar 1 .

Tabel 1. Rendemen biodiesel minyak biji nyamplung

\begin{tabular}{|c|c|c|}
\hline No & $\begin{array}{c}\text { Waktu reaksi } \\
\text { (menit) }\end{array}$ & Hasil rendemen (\%) \\
\hline 1 & 45 & 27,0900 \\
\hline 2 & 60 & 25,6201 \\
\hline 3 & 75 & 42,7399 \\
\hline
\end{tabular}

Data spektrum yang dihasilkan pada masingmasing variasi reaksi menunjukkan bahwa dua dari tiga variasi reaksi tersebut memiliki gugus khas metil ester yaitu waktu reaksi 45 menit dan 75 menit sedangkan waktu reaksi 60 menit pita serapannya melebar dan memiliki pita serapan $\mathrm{O}-\mathrm{H}$ yang sangat lebar yang mengindikasikan adanya molekul air. Pitapita serapan khas dari asam lemak rantai panjang diantaranya vibrasi regang $\mathrm{C}-\mathrm{O}$ pada daerah frekuensi sekitar 1236,37; 1170,79 dan 1195,87; pita serapan regangan $\mathrm{C}-\mathrm{H}$ alkana pada frekuensi 2852,72; dan gugus metil pada frekuensi 2924,09. Pita serapan regang $\mathrm{C}=\mathrm{O}$ terdeteksi pada frekuensi 1741,72 yang sangat jelas terlihat sebagai pita kuat di area pertengahan spektrum. Pita serapan vibrasi regang $\mathrm{C}=\mathrm{C}$ pada panjang gelombang 1641,42 menunjukkan bahwa komponen biodiesel mengandung ikatan rangkap. Dengan demikian gugus fungsi yang terdapat pada biodiesel minyak biji nyamplung yang dianalisis dengan FTIR antara lain gugus metil, gugus ester serta gugus karbonil.

\section{Analisa metil ester menggunakan GC-MS}

Selain analisa menggunakan FTIR, pada penelitian ini juga menggunakan alat instrumen GCMS. GC-MS digunakan untuk mengetahui komponen asam lemak dan kadar asam lemak tersebut dalam biodiesel minyak biji nyamplung yang direaksikan dengan metode ultrasonokimia. Berdasarkan hasil analisis diperoleh masing-masing empat puncak komponen mayor pada variasi waktu 45 menit dan 60 menit dan tiga komponen mayor untuk reaksi 75 menit.

Biodiesel yang dihasilkan pada semua waktu reaksi secara umum menunjukkan bahwa senyawa utama dari biodiesel minyak nyamplung adalah metil ester oleat $(\mathrm{m} / \mathrm{z}=296)$. Persentase terbanyak kedua pada waktu reaksi 45 menit berbeda dengan waktu reaksi 60 menit dan 75 menit. Pada waktu reaksi 45 menit, komponen mayor terbanyak kedua adalah metil ester linoleat sedangkan pada waktu reaksi 60 menit dan 75 adalah metil ester stearat. Komponen mayor terbanyak ketiga pada waktu reaksi 45 menit 
yaitu metil ester stearat berbeda dengan waktu reaksi 60 menit dan 75 menit yaitu metil ester palmitat.

Komponen mayor yang paling banyak terdapat pada biodiesel minyak nyamplung seperti terlihat pada grafik fragmen-fragmen berikut adalah metil ester oleat. Metil ester oleat merupakan senyawa yang memiliki massa 296. Fragmentasi metil ester oleat dapat dilihar pada Gambar 2. Pada fragmen senyawa yang diidentifikasi memiliki rumus molekul $\mathrm{C}_{19} \mathrm{H}_{36} \mathrm{O}_{2}$. Senyawa yang teridentifikasi tersebut mengalami penguraian dari berat molekul m/z 296 menjadi 254 dengan selisih 42 dimana rumus molekul yang mirip dengan jumlah selisih tersebut adalah $\mathrm{C}_{3} \mathrm{H}_{6}$ atau propena yang berarti ion molekul telah mengalami penguraian sehingga melepaskan molekul propena, kemudian fragmen tersebut melepaskan ion molekul $\mathrm{C}_{8} \mathrm{H}_{18}$ atau oktana sehingga menghasilkan puncak pada $\mathrm{m} / \mathrm{z}$ 152. Selanjutnya dilepaskan ion molekul $\mathrm{C}_{6} \mathrm{H}_{11}$ berdasarkan pola fragmentasi 152 menjadi 69 yamg mempunyai selisih 83.

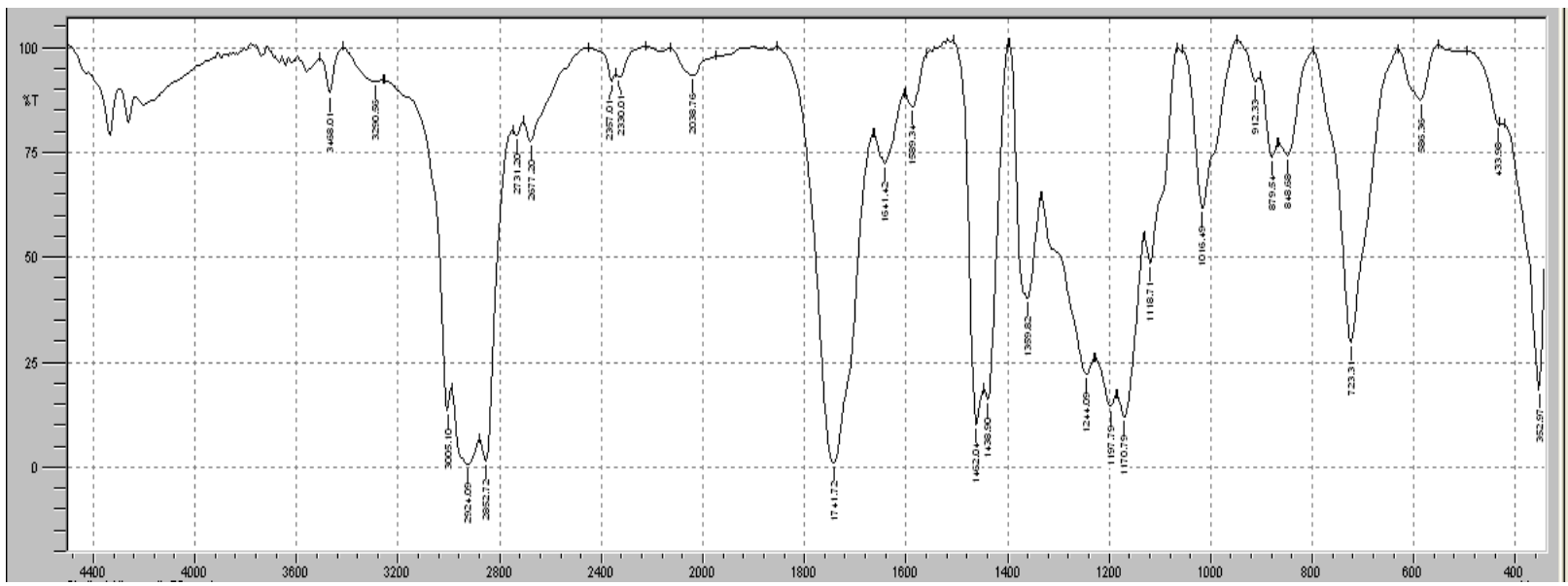

Gambar 1 Pita serapan biodiesel reaksi 45 menit

Tabel 2 Komponen mayor berdasarkan hasil analisa GC-MS

\begin{tabular}{|c|c|c|c|l|c|}
\hline No & $\begin{array}{c}\text { Waktu } \\
\text { reaksi }\end{array}$ & Puncak & $\begin{array}{c}\text { Waktu } \\
\text { deteksi }\end{array}$ & \multicolumn{1}{|c|}{$\begin{array}{c}\text { Senyawa } \\
\text { Teridentifikasi }\end{array}$} & Persentase (\%) \\
\hline 1 & \multirow{2}{*}{45 menit } & 1 & 19,793 & Metil ester palmitat & 13,827 \\
\cline { 3 - 6 } & & 2 & 21,432 & Metil ester linoleat & 23,698 \\
\cline { 3 - 6 } & & 3 & 21,503 & Metil ester oleat & 43,861 \\
\cline { 3 - 6 } & \multirow{2}{*}{60 menit } & 1 & 21,695 & Metil ester stearat & 17,531 \\
\cline { 3 - 6 } & & 2 & 21,806 & Metil ester palmitat & 13,987 \\
\cline { 3 - 6 } & & 3 & 21,528 & Metil ester linoleat & 7,241 \\
\cline { 3 - 6 } & & 4 & 21,721 & Metil ester oleat & 42,301 \\
\hline 3 & \multirow{2}{*}{75 menit } & 1 & 19,838 & Metil ester palmitat & 18,562 \\
\cline { 3 - 6 } & & 2 & 21,586 & Metil ester oleat & 53,609 \\
\cline { 3 - 6 } & & 3 & 21,766 & Metil ester stearat & 21,089 \\
\hline
\end{tabular}

Tabel 3 Senyawa yang dihasilkan dari analisa GC-MS

\begin{tabular}{|l|l|l|l|l|}
\hline No & $\begin{array}{l}\text { Waktu } \\
\text { reaksi }\end{array}$ & Senyawa teridentifikasi & Rumus molekul & Pola fragmentasi \\
\hline \multirow{3}{*}{1} & 45 menit & Metil ester palmitat & $\mathrm{C}_{17} \mathrm{H}_{34} \mathrm{O}_{2}$ & $270 ; 227 ; 43 ; 87 ; 74$ \\
\cline { 3 - 5 } & & Metil ester linoleat & $\mathrm{C}_{19} \mathrm{H}_{29} \mathrm{O}_{2}$ & $294 ; 263 ; 67 ; 55 ; 41$ \\
\cline { 3 - 5 } & & Metil ester oleat & $\mathrm{C}_{19} \mathrm{H}_{36} \mathrm{O}_{2}$ & $296 ; 264 ; 69 ; 55 ; 43$ \\
\cline { 3 - 5 } & & Metil ester stearat & $\mathrm{C}_{19} \mathrm{H}_{38} \mathrm{O}_{2}$ & $298 ; 255 ; 87 ; 74 ; 43$ \\
\hline \multirow{2}{*}{60 menit } & Metil ester palmitat & $\mathrm{C}_{17} \mathrm{H}_{34} \mathrm{O}_{2}$ & $270 ; 227 ; 43 ; 87 ; 74$ \\
\cline { 3 - 5 } & & Metil ester linoleat & $\mathrm{C}_{19} \mathrm{H}_{29} \mathrm{O}_{2}$ & $294 ; 263 ; 67 ; 55 ; 41$ \\
\cline { 3 - 5 } & & Metil ester oleat & $\mathrm{C}_{19} \mathrm{H}_{36} \mathrm{O}_{2}$ & $296 ; 264 ; 69 ; 55 ; 43$ \\
\cline { 3 - 5 } & & Metil ester stearat & $\mathrm{C}_{19} \mathrm{H}_{38} \mathrm{O}_{2}$ & $298 ; 255 ; 87 ; 74 ; 43$ \\
\hline \multirow{3}{*}{3} & \multirow{2}{*}{75 menit } & Metil ester palmitat & $\mathrm{C}_{17} \mathrm{H}_{34} \mathrm{O}_{2}$ & $270 ; 227 ; 43 ; 87 ; 74$ \\
\cline { 3 - 5 } & & Metil ester oleat & $\mathrm{C}_{19} \mathrm{H}_{36} \mathrm{O}_{2}$ & $296 ; 264 ; 69 ; 55 ; 43$ \\
\cline { 3 - 5 } & & Metil ester stearat & $\mathrm{C}_{19} \mathrm{H}_{38} \mathrm{O}_{2}$ & $298 ; 255 ; 87 ; 74 ; 43$ \\
\hline
\end{tabular}




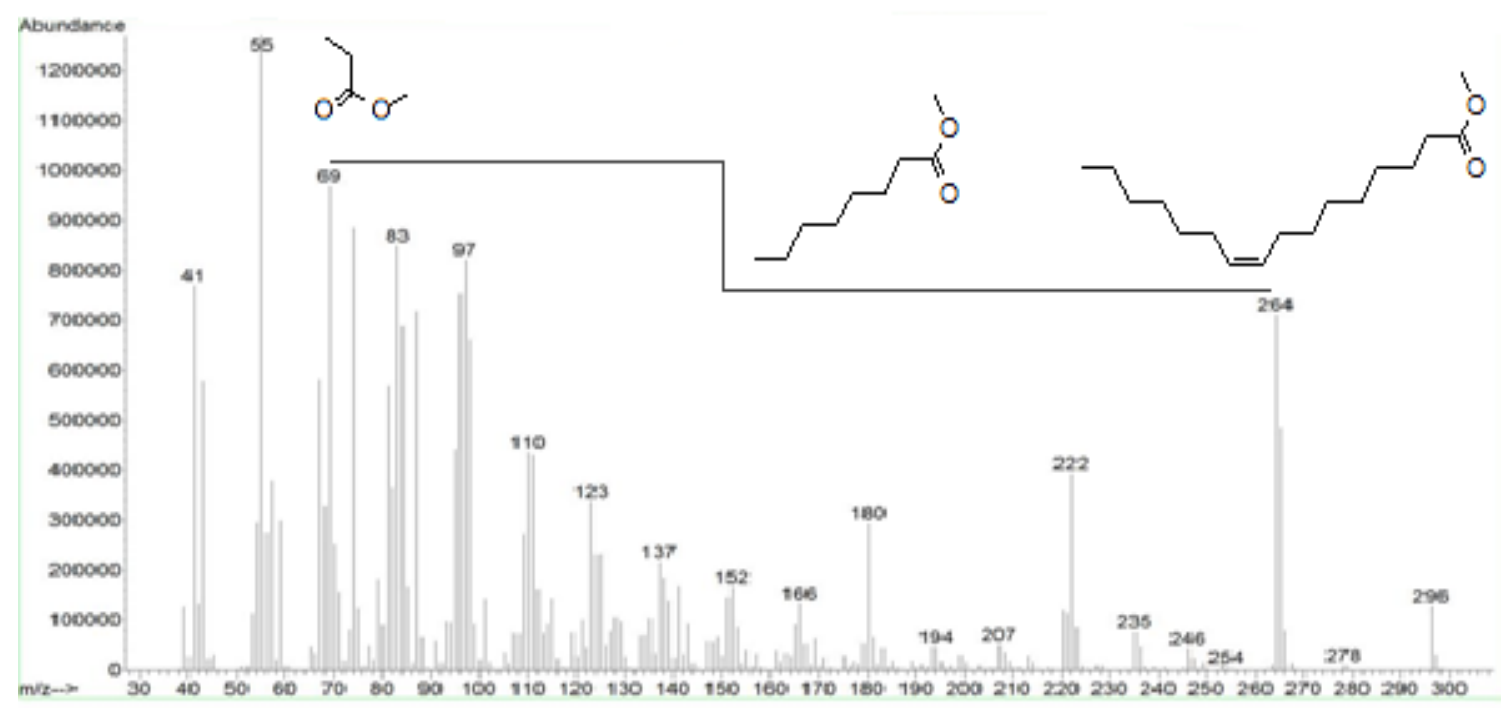

Gambar 2 Fragmentasi metil ester oleat

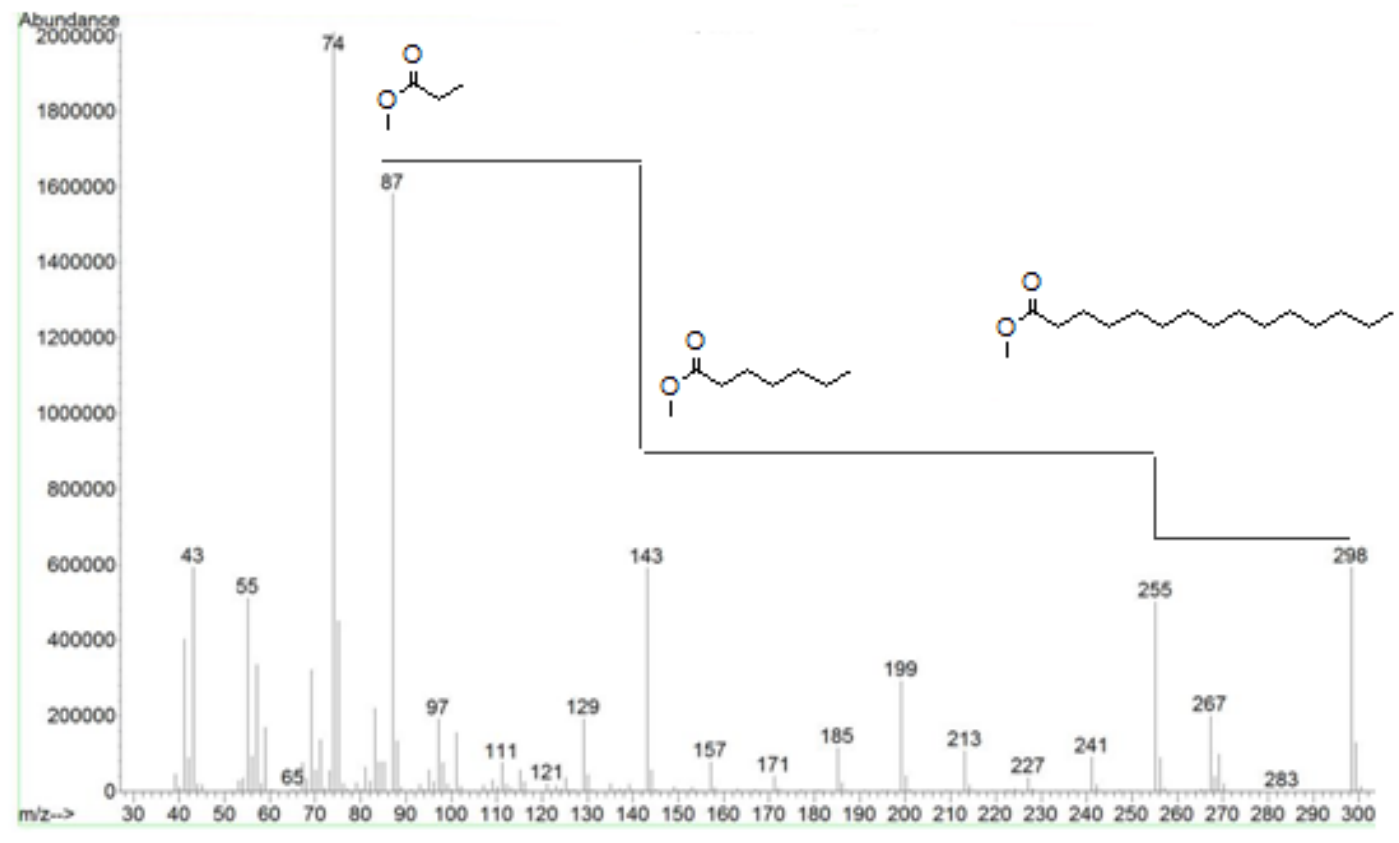

Gambar 3 pola fragmentasi metil ester stearat

Komponen mayor paling banyak kedua dari hasil analisa GC-MS biodiesel minyak biji nyamplung adalah metil ester stearat. Metil ester stearat merupakan senyawa yang memiliki massa 298. Fragmentasi dari metil ester stearat disajikan pada Gambar 3.

Hasil fragmentasi komponen mayor yang dianalisa merupakan senyawa yang memiliki rumus molekul $\mathrm{C}_{18} \mathrm{H}_{36} \mathrm{O}_{2}$. Pola fragmentasi dengan puncak ion molekul m/z 298 menunjukkan bahwa komponen tersebut adalah metil stearat. Ion molekul ini kemudian mengalami penguraian dengan melepaskan molekul $\mathrm{C}_{2} \mathrm{H}_{5}$ sehingga menghasilkan puncak pada m/z 283 yang memiliki selisih sebesar 29. Kemudian melepas molekul $\mathrm{C}_{2} \mathrm{H}_{4}$ hingga menghasilkan puncak pada $\mathrm{m} / \mathrm{z} 255$. Puncak pada $\mathrm{m} / \mathrm{z} 143$ menandakan ion molekul menguraikan molekul $\mathrm{C}_{8} \mathrm{H}_{16}$ lalu melepaskan molekul $\mathrm{C}_{4} \mathrm{H}_{8}$ pada puncak m/z 87 yang memiliki selisih 56.

Komponen mayor yang memiliki persentase terbanyak ketiga adalah metil ester palmitat. Dari hasil analisa GC-MS, metil ester palmitat memiliki massa 270. Pola fragmentasi metil ester palmitat dapat dilihat pada Gambar 4. 


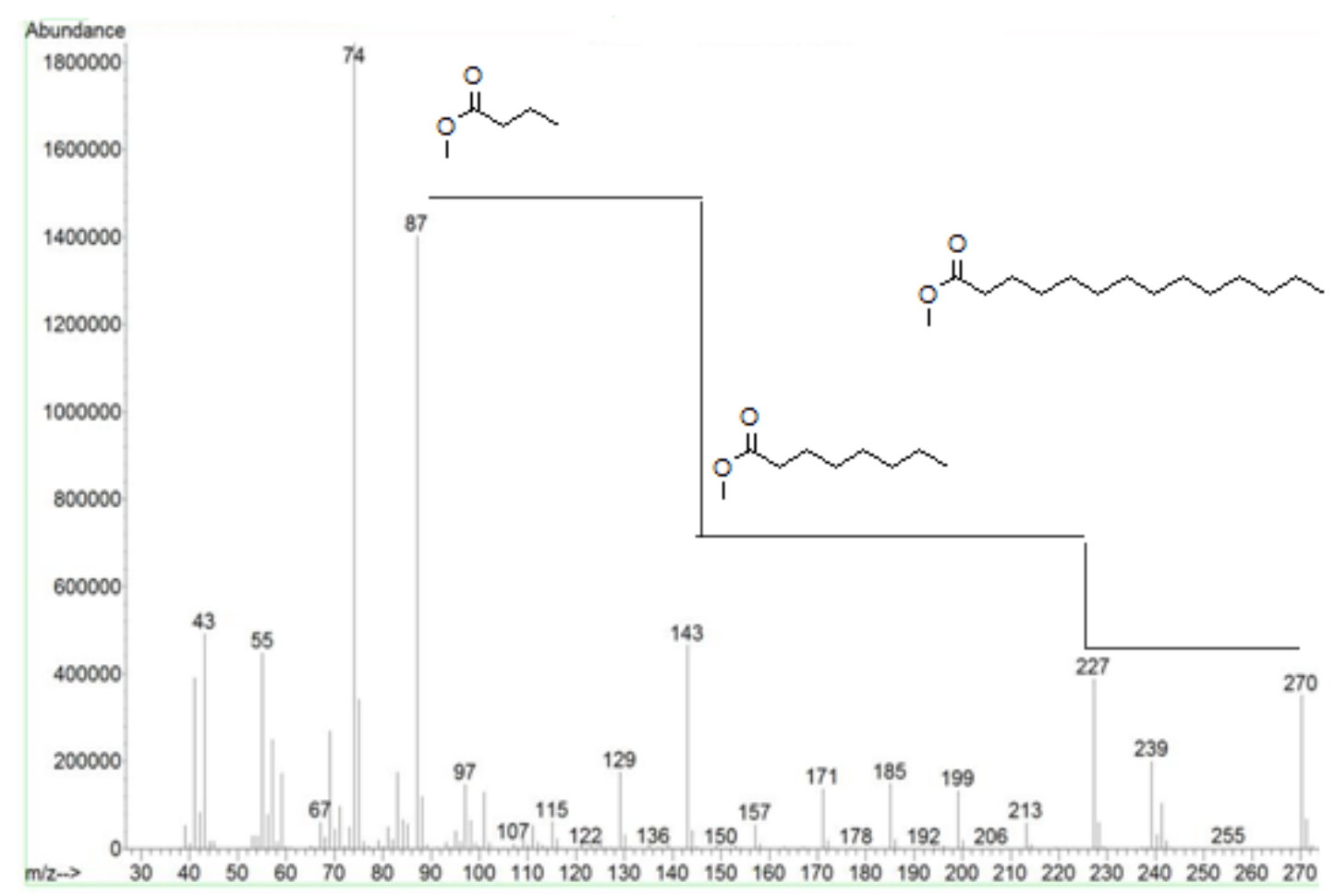

Gambar 4 Pola fragmentasi metil ester palmitat

Pada gambar di atas komponen senyawa yang diidentifikasi memiliki rumus molekul $\mathrm{C}_{17} \mathrm{H}_{34} \mathrm{O}_{2}$. Senyawa yang kelimpahan molekulnya sebesar 270 tersebut diidentifikasi sebagai metil ester palmitat. Pola fragmentasi metil ester palmitat adalah sebagai berikut. Ion molekul melepaskan molekul $\mathrm{C}_{3} \mathrm{H}_{7}$ sehingga menghasilkan puncak pada m/z 227. Kemudian fragmen tersebut melepaskan molekul $\mathrm{C}_{6} \mathrm{H}_{12}$ yang dihasilkan puncak pada m/z 143 dengan selisih sebasar 84. Selanjutnya dilepaskan lagi molekul $\mathrm{C}_{4} \mathrm{H}_{8}$ yang menghasilkan puncak $\mathrm{m} / \mathrm{z} 87$ yang memiliki selisih 84 .

\section{KESIMPULAN}

Nilai konversi optimal yang didapatkan dari sintesis biodiesel minyak nyamplung menggunakan metode ultrasonokimia adalah $42,7399 \%$ pada waktu reaksi 75 menit.

Senyawa asam lemak metil ester yang menjadi penyusun biodiesel minyak biji nyamplung menggunakan metode ultrasonokimia adalah: metil ester palmitat, metil ester linoleat, metil ester oleat dan metil ester stearat.

\section{DAFTAR PUSTAKA}

Budiyanto, Daulay, H.B. \& Aldiona, A.F. (2012). Optimalisasi kimerja pembuatan dan peningkatan kualitas biodiesel dari fraksi minyak limbah cair pengolahan kelapa sawit dengan memanfaatkan gelombang ultrasonik. Jurnal Teknologi Industri Pertanian. 22 (1), $10-14$.

Dang, X., Fang, Z. \& Liu, Y.-H. (2010). Ultrasonic transesterificasion of Jatropha curcas L. oil by a two step process. Energy Conversion and Management. 51 (12), 2802-2807.

Frederic, N.P. (2013). Pembuatan Biodiesel dari Minyak Biji Kapok dengan Proses Esterifikasi Transesterifikasi. Jurnal Teknologi Kimia dan Industri. 2(2), 262-266.

PUSDATIN ESDM. (2012). Handbook of Energy and Economic Statistic of Indonesia 2012. Jakarta: Kementerian Energi dan Sumber Daya Mineral.

Lembaga Riset Perkebunan Indonesia. (2008). Biodiesel: Energi Terbarukan Ramah Lingkungan. Warta Penelitian dan Pengembangan Pertanian. 30(4), 3-4.

Putri, S.K. Supranto \& Sudiyo, R. (2012). Studi Proses Pembuatan Biodiesel dari Minyak Kelapa (Coconut Oil) dengan Bantuan Gelombang Ultrasonik. Jurnal Rekayasa Proses. 6(1), 20-25.

Suirta, I.W. (2009). Preparasi biodiesel dari minyak jelantah kelapa sawit. Jurnal Kimia. 3(1), 1-6. 